\title{
Editorial
}

\section{INFORMÁTICA PARA BIODIVERSIDADE: vencendo desafios e explorando oportunidades}

O espectro de atuação da gestão da informação sobre biodiversidade ultrapassa em muito a percepção mais comum de seu papel, freqüentemente associado ao apoio a projetos para o manejo de seus componentes (diversidade intra-específica, específica e de ecossistemas). Sistemas de informação complexos de apoio à tomada de decisão são hoje concebidos para conciliar desenvolvimento econômico com a preservação dos recursos naturais e qualidade ambiental. No momento em que lideranças nacionais expressam que a política ambiental deixará de ser a política do "não" para passar a ser a do "sim, mas sabendo como", aumenta em muito a importância do uso de tecnologias avançadas de informação aplicadas a sistemas distribuídos e interoperáveis de gestão da biodiversidade. (http://www.cria.org.br/eventos/tdbi/bis/marcio).

Esta promissora nova abordagem exige investimentos expressivos em tecnologia de informação para tratar da complexidade da informação em biodiversidade, unindo em torno de objetivos específicos dados de natureza biológica (genes e suas funções, por exemplo), dados físico-químicos (imagens de satélite) e dados sociais e culturais (práticas tradicionais, preferências de consumo, etc.). Isto é particularmente importante para o Brasil, país ávido por crescimento econômico e social e dotado da maior biodiversidade do planeta. Preparar nossas instituições para enfrentar este desafio e aproveitar as oportunidades de geração de tecnologias passíveis de serem apropriadas por setores estratégicos da nossa economia, justifica plenamente a resposta dada pela FAPESP às demandas da comunidade científica do Estado de São Paulo na implementação do Instituto Virtual da Biodiversidade - BIOTA/FAPESP, integrando as Universidades, Institutos de Pesquisa, Centros da Embrapa e ONGs do Estado aos especialistas do país e do exterior no esforço de construção de base de conhecimento sobre a biodiversidade dos biomas estaduais.

Mais do que prover a infra-estrutura necessária e fomentar a formação de pessoal, a promoção de uma cultura de uso de software de domínio público e o compartilhamento de dados entre os mais de 500 pesquisadores do BIOTA/FAPESP constituem-se em importantes conquistas para que este projeto se apresente vitorioso e mantenha os cientistas e técnicos envolvidos em posição de grande destaque no cenário internacional, conforme comprova eventorecente coordenado pelo Centro de Referência em Informação Ambiental - CRIA.

Trata-se, portanto, de projeto de natureza estratégica e estruturante, com imenso potencial de utilização em outras regiões do país, e que assenta as bases para a incorporação da informação sobre biodiversidade em políticas públicas de gestão da própria biodiversidade e dos recursos hídricos, de zoneamento agrícola, além de outras voltadas para a produção de energia e a promoção do eco-turismo.

A revista Biota Neotropica se insere neste esforço ao proporcionar o espaço de interação que se faz necessário ao complexo processo de inovação tecnológica que une as conquistas recentes da genética e da biologia molecular ao conhecimento sobre a nossa biodiversidade, cuja gestão é altamente dependente de tecnologia de informação. 


\section{Marcio de Miranda Santos}

Diretor Executivo do Centro de Gestão e Estudos Estratégicos - CGEE

José Fernando Perez

Diretor Científico da Fundação de Amparo à Pesquisa do Estado de São Paulo FAPESP 